\title{
High prevalence of parental delivery of plastic debris in Cory's shearwaters (Calonectris diomedea)
}

\author{
Airam Rodríguez ${ }^{\mathrm{a}, \Uparrow}$, Beneharo Rodríguez ${ }^{\mathrm{b}}$, María Nazaret Carrasco ${ }^{\mathrm{b}}$ \\ ${ }^{a}$ Department of Evolutionary Ecology, Estación Biológica de Doñana (CSIC), Avda. Américo Vespucio s/n, 41092 Seville, Spain \\ ${ }^{\mathrm{b}}$ La Malecita s/n, Buenavista del Norte, S/C de Tenerife, 38480 Canary Islands, Spain
}

Keywords:

Canary Islands

Canary Current

Light pollution

Marine plastic debris

North Atlantic Ocean

Plastic ingestion

\begin{abstract}
a b s t r a c t
Plastic ingestion by adult Procellariiformes has been widely recorded, but few studies have evaluated intergenerational transfer. We assessed the prevalence of plastic particles, as well as their basic characteristics, in the gut content of dead Cory's shearwater fledglings stranded by light pollution on Canary Islands. Eighty-three percent of birds were affected, containing on average 8.0 plastic pieces per bird. The average plastic weight per bird was low $(2.97 \pm 3.97 \mathrm{mg})$ compared with other petrel species. We found no relationships between plastic loads and body condition or body size, but negative effects may be hidden or delayed. We propose to use the fledglings stranded by light pollution to carry out more precise studies to understand the potential hidden costs of plastic ingestion; and to monitor in a long-term the marine debris to develop management actions for the control of pollution at the marine environment.
\end{abstract}

Plastics have brought important benefits to humanity such as health, safety, energy savings or material conservation (Andrady and Neal, 2009), but they have also brought concerns about their accumulation in the environment and transfer of chemicals to wildlife and humans (Thompson et al., 2009). Important amounts of plastic debris are widely distributed in all habitats, especially in the oceans, from the sea surface to the bottom (Barnes et al., 2009). This debris negatively affects marine biota, including fishes, turtles, birds and mammals, basically by entanglement and ingestion (Laist, 1987; Derraik, 2002; Gregory, 2009). Plastic ingestion by seabirds has been widely recorded, being Procellariiformes the most affected order (more than 63\% of species; Laist, 1997). Despite the voluminous information on ingested plastic debris by adults across the world (e.g. Colabuono et al., 2009; Hyrenbach et al., 2009; van Franeker et al., 2011; Yamashita et al., 2011), the transfer of plastic debris from parents to fledglings has been studied in a limited number of species, mainly from the Pacific Ocean (Hutton et al., 2008; Young et al., 2009; Bester et al., 2010; Carey, 2011; see also Copello et al., 2008).

Monitoring the incidence of plastic ingestion is crucial to assess temporal trends of marine plastic debris and their potential effects on fitness of individuals (Vlietstra and Parga, 2002; van Franeker et al., 2011). Furthermore, studying the gut contents of seabirds is a cost-effective way to monitor plastic debris at sea (Ryan, 2008; Ryan et al., 2009). In this study, we evaluate the prevalence of plastic debris ingested by Cory's shearwater (Calonectris diomedea)

\footnotetext{
$\Uparrow$ Corresponding author. Tel.: +34 954232340; fax: +34 954621125 . E-mail addresses: airamrguez@ebd.csic.es, airamrguez@gmail.com (A. Rodríguez).
}

fledglings in the Canary Islands, North Atlantic Ocean, as well as potential differences between sexes, years and date of fledging. Furthermore, we assess the effect of plastics on the fitness of fledglings measured as body condition and body size indices. Finally, we provide a description of plastic items, including size, mass, color, and type.

During their first flights to the sea, many Cory's shearwater fledglings become disoriented and end up stranded by artificial lights on Tenerife, the largest island of the Canary Islands (Rodríguez and Rodríguez, 2009). Every year around 1,000 fledglings are collected and recovered during the rescue campaigns carried out by La Tahonilla wildlife rehabilitation center (depending on the local government), NGOs and civil cooperation (although an increase in the number of rescued birds has been recorded since rescue campaigns were established; see Rodríguez et al., 2012a). The majority of them $(>95 \%)$ are released into the sea, but some fledglings are found dead or agonizing whereas still some others have to be euthanized if they cannot be rehabilitated (Rodríguez and Rodríguez, 2009).

During 2009-2011 fledging seasons (October-November), at least 85 fledglings died or were euthanized by rehabilitation center personnel in Tenerife Island. Corpses were frozen at $-20^{\circ} \mathrm{C}$ for later analysis. For every bird, date, body mass and six morphometric measurements (wing, tarsus, culmen, bill length at nostril, bill depth and bill depth at nostril) were obtained. The biometrics were taken using a spring balance $( \pm 10 \mathrm{~g}$ ), a ruler (nearest $1 \mathrm{~mm}$ ) and a digital caliper $( \pm 0.01 \mathrm{~mm})$. We conducted a principal component analysis with the six morphometric measurements and the first principal component was used as a body size index (BSI). A body condition index (BCI) was calculated as the standardized residuals 
Table 1

Sources of variation for number, mean length and mass of ingested plastics by Cory's shearwater fledglings after applying general linear models.

\begin{tabular}{|c|c|c|c|c|c|c|}
\hline \multirow[t]{3}{*}{ Independent variables } & \multicolumn{6}{|c|}{ Response variables } \\
\hline & \multicolumn{2}{|c|}{ Number of plastics ${ }^{a}$} & \multicolumn{2}{|c|}{ Mean length of plastics ${ }^{a}$} & \multicolumn{2}{|c|}{ Ingested plastic mass $^{a}$} \\
\hline & Estimate \pm SE & $\mathrm{P}$ & Estimate \pm SE & $\mathrm{P}$ & Estimate $\pm \mathrm{SE}$ & $\mathrm{P}$ \\
\hline Intersection & $-1.79 \pm 3.11$ & 0.629 & $-1.77 \pm 2.09$ & 0.379 & $-2.88 \pm 3.72$ & 0.443 \\
\hline Year & & 0.005 & & 0.165 & & 0.010 \\
\hline 2009 & $0.03 \pm 0.18$ & & $-0.23 \pm 0.12$ & & $-0.25 \pm 0.21$ & \\
\hline 2010 & $0.40 \pm 0.14$ & & $-0.07 \pm 0.09$ & & $0.29 \pm 0.16$ & \\
\hline 2011 & 0 & & 0 & & 0 & \\
\hline Sex & & 0.381 & & 0.747 & & 0.550 \\
\hline Female & $0.10 \pm 0.11$ & & $-0.02 \pm 0.08$ & & $-0.08 \pm 0.13$ & \\
\hline Male & 0 & & 0 & & 0 & \\
\hline Date of fledging & $0.01 \pm 0.01$ & 0.500 & $0.01 \pm 0.01$ & 0.211 & $0.00 \pm 0.01$ & 0.806 \\
\hline
\end{tabular}

Significant P-values are in bold.

${ }^{a}$ Log-transformed variable.

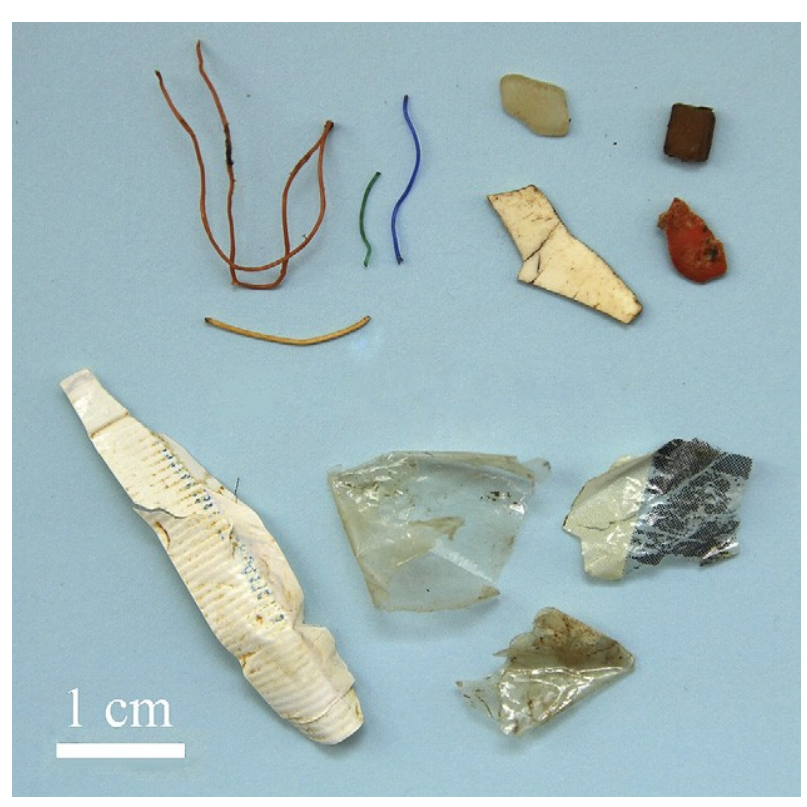

Fig. 1. Examples of plastic items found in the proventriculus and gizzard of Cory's shearwater (Calonectris diomedea) fledglings on Tenerife, Canary Islands.

of an ordinary least square regression between body mass on body size index (see Rodríguez et al., 2012b for procedures). Birds were molecularly sexed following Rodríguez et al. (2012b) (45 males and 40 females).

After recording the biometrics, we dissected the dead birds to separate the intestine, proventriculus and ventriculus. Gut content was isolated and rinsed in clean water. We looked for plastic items discarding particles shorter than $1 \mathrm{~mm}$ because it is a very time consuming task and they contribute little to plastic mass (van Franeker et al., 2011). We categorized plastic debris by type (nylon and irregular particles) and color, and we weighed them using a digital balance $( \pm 0.0001 \mathrm{~g})$ and measured its maximum length (nearest $0.5 \mathrm{~mm}$ ). We also isolated food remains (only cephalopods beaks, the most abundant recognizable food item) and natural debris (wood, feathers and stones), and after being air dried, plastic particles were counted and both particles types, beaks and natural debris, weighed.

We used likelihood ratio tests to evaluate the incidence of plastic ingestion between years and sexes. To test the hypothesis that ingested plastics reduce food intake we evaluated the relationship between plastics and food remains by means of correlations. We applied general linear models to evaluate (1) the differences in the characteristics (number, mass and mean length) of plastic

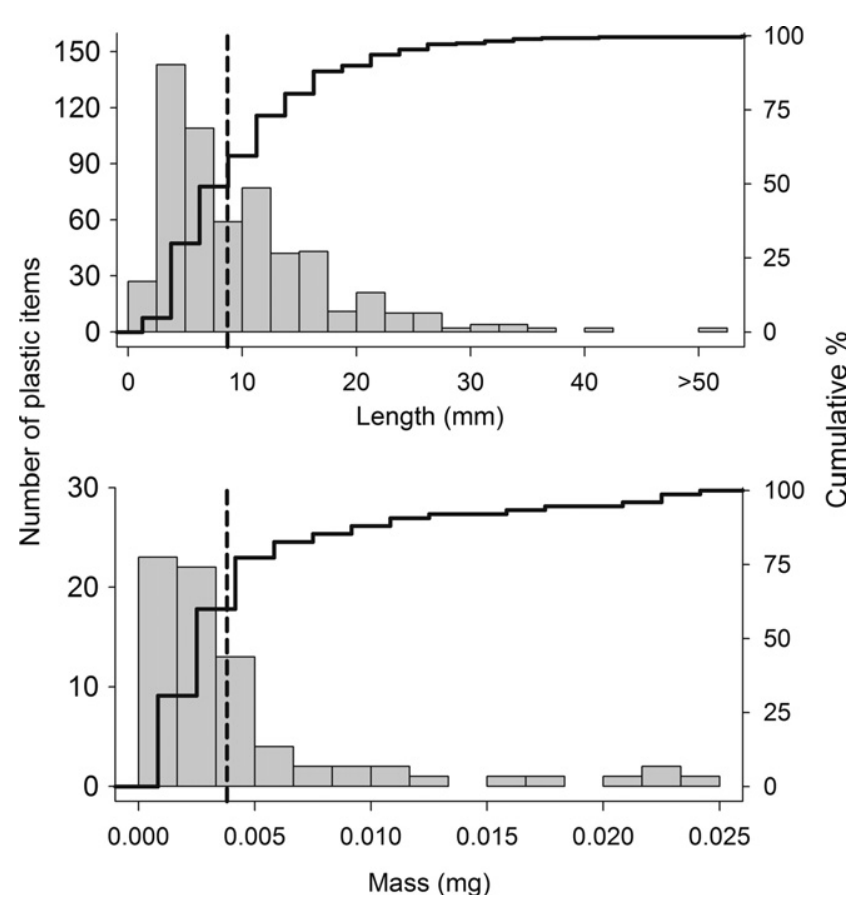

Fig. 2. Size and mass of plastic items ingested by Cory's shearwater (Calonectris diomedea) fledglings. Solid and dashed lines represent the cumulative percentage and the mean values, respectively. Mass histogram is based on a subsample of 75 plastic items.

ingested by fledglings between years, sexes and date of fledglings (Table 1); and (2) the effect of plastics on body condition and body size. We built models with BCI and BSI as response variables and separately included number, mean length, maximum length and mass of plastics as covariates. In BCI models, date of fledging was always included as a covariate, because it is strongly correlated with condition. In BSI models, sex was included as a factor because of the evident sexual dimorphism of the species (see Rodríguez et al., 2012b).

When normality assumptions were not reached, variables were log-transformed, except maximum length (squared root transformed). Statistical analyses were conducted in SPSS v.19.0 software.

In total, 568 plastic particles were recovered, 314 (55.3\%) being nylon lines and the remaining 254 (44.7\%) being irregular plastic pieces (Fig. 1). The mean number of plastic particles recovered per bird was $8.0 \pm 7.9$, ranging from 1 to 36 . The mean length of nylon lines and irregular plastics were $12.7 \pm 8.0 \mathrm{~mm}$ (max length $=75 \mathrm{~mm}$ ) and $3.9 \pm 3.5$ (max length $=35 \mathrm{~mm}$ ), respectively. The mean length of plastic items and mean mass of plastic load 

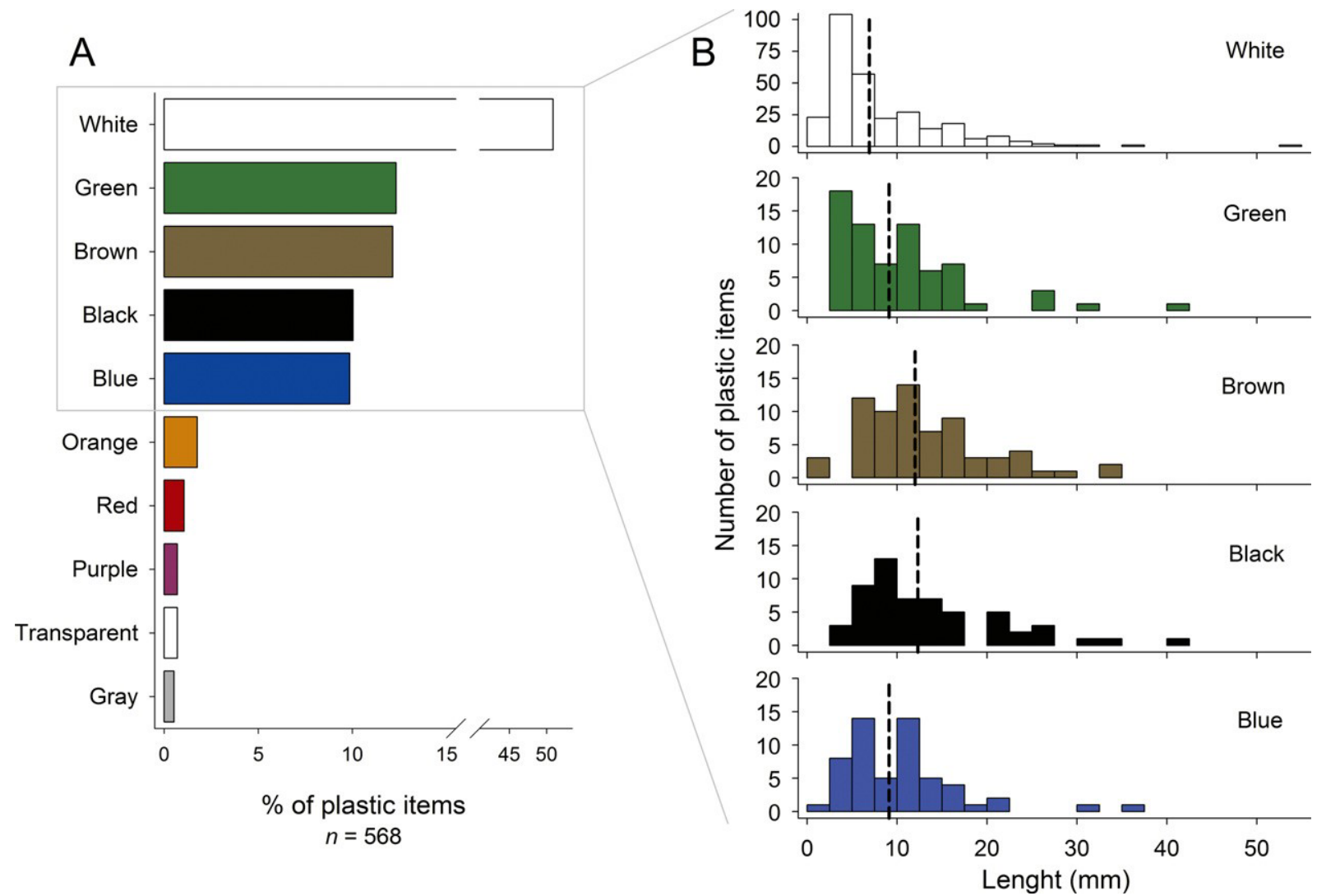

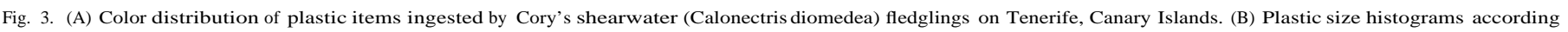
to the most abundant colors. Vertical dashed lines represent the mean values.

were $8.7 \pm 7.7 \mathrm{~mm}$ and $3.8 \pm 5.4 \mathrm{mg}$ (Fig. 2). The mean weight of plastic objects was $2.97 \pm 3.97$, ranging from 0.1 to $39.3 \mathrm{mg}$. The number of plastic items and the total mass of ingested plastic were highly correlated (Pearson's Coefficient $=0.679, \mathrm{P}<0.001$ ).

At least nine colors were clearly distinguished, but the majority of items were white colored (50.9\%, Fig. 3a). Length of plastics items varied according to their colors $\left(\mathrm{F}_{4},{ }_{536}=20.098, \mathrm{P}<0.001\right)$, white items being shorter than other colors (Fig. 3b). According to our models, the abundance of plastics (number and mass of items) depended on years. However, mean length of plastics was similar between years and sexes. Date of fledging had no impact on the plastic features (Table 1 ).

Seventy-one out of 85 (83.5\%) Cory's shearwater fledglings contained plastic particles in their guts. Prevalence of plastic ingestion, in terms of number of affected fledglings, did not vary between sexes or years $\left(\mathrm{G}=0.879, \mathrm{P}=0.349\right.$ and $\mathrm{G}_{2}=0.367, \mathrm{P}=0.832$, respectively). We did not find any relationship between the number of food items (squid beaks) and the number of plastics (Pearson's Coefficient = $-0.071, \mathrm{P}=0.560$ ) nor between total mass of ingested plastics and total mass of other remains (food remains and natural debris), the total mass of neutral debris or the total mass of squid beaks (all Pearson's Coefficients $<0.089$, all P-values $>0.459$ ). Neither body condition index nor body size index were explained by any plastic variables (number, mean length, maximum length and mass of plastics). For both indices, the number of plastic items reached the lowest P-values (0.344 and 0.581, respectively; see Fig. 4).

We have studied plastic ingestion by fledglings stranded by light pollution in the Canary Islands. To our knowledge, our study is the first one evaluating parental transfer of plastics in Cory's shearwater fledglings, as well as the first description of plastic ingestion by seabirds in the Canary Islands. That is of special relevance given that adult individuals forage in the Canary current (Arcos et al., 2009), where one of the most important fisheries in the world occurs nowadays. Thus, the information presented here can be used as an indicator of plastic pollution in a marine ecosystem providing vital food and economic resources for much of Western Africa and Europe (Campredon and Cuq, 2001; Alder and Sumaila, 2004). In fact, more than $50 \%$ of plastic items were clearly related to shipping or fisheries activities, i.e., nylon lines coming from ropes, fishing nets or any other fishing gear.

The incidence (occurrence and number) of plastics is similar to the one recorded for adult birds of the species during the non-breeding season off the Brazilian coast (Petry et al., 2009; Colabuono et al., 2009), but also for fledglings of other shearwater species such as the flesh-footed shearwater Puffinus carneipes, the wedge-tailed shearwater Puffinus pacificus on Lord Howe Island, or the short-tailed shearwater Puffinus tenuirostris on Phillip Island (see Hutton et al., 2008; Carey, 2011). Intergenerational transfer of plastics seems to be common in Procellariiformes (Copello et al., 2008; Hutton et al., 2008; Young et al., 2009; Bester et al., 2010; Carey, 2011; this study), and contrasts with the low incidence in other seabirds, as for example auklets, where plastics occurred in only one out of 2541 analyzed chick meals (Bond et al., 2010). In this sense, Procellariiformes can accumulate plastics in the digestive tract, while other seabirds can easily regurgitate them (e.g. gulls and skuas). Thus, the Cory's shearwater fledglings studied here could be accumulating plastic since they hatched in mid-July (i.e., during a 95-120 days period). The plastic mass ingested by Cory's shearwaters is low compared with other petrel species (Ryan, 1987b; Moser and Lee, 1992; this study). Thus, the critical level of $0.1 \mathrm{~g}$ of plastic proposed by the OSPAR commission was exceeded by $58 \%$ of fulmars Fulmarus glacilis in the North Sea (see van 

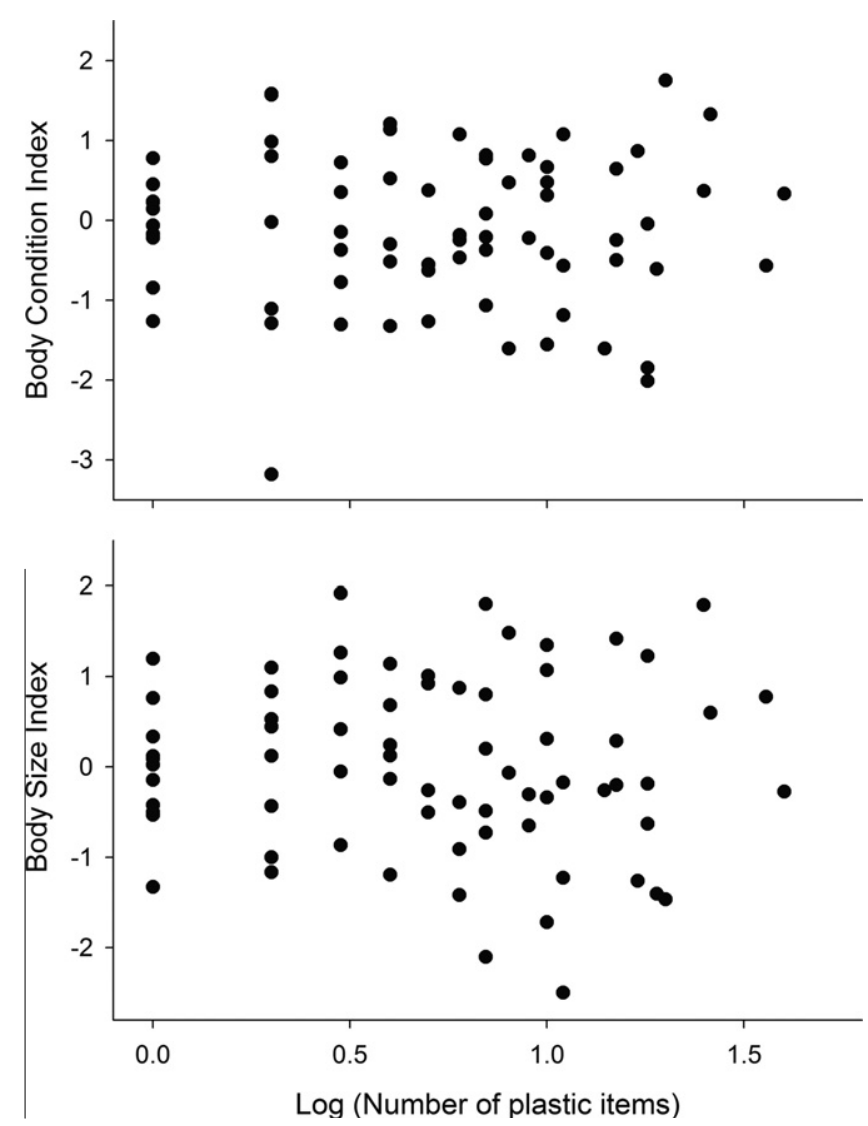

Fig. 4. No relationships between the number of ingested plastic items and body condition and body size indices, in Cory's shearwater (Calonectris diomedea) fledglings.

Franeker et al., 2011). This value contrasts with our findings in a similarly sized species; only two out of 85 Cory's shearwater fledglings exceeded this arbitrary threshold.

Plastic ingested may cause perforation or ulceration, reduce the space for food in the guts provoking early satiation, or lead to starvation and general debilitation (Ryan, 1988; Gregory, 2009). Negative correlations between plastic loads and physical condition (body mass) have been recorded in several species (e.g. Ryan, 1987a; Spear et al., 1995). We failed to find any relationship between body condition or body size indexes and the number, the size or the total mass of ingested plastics (see Fig. 4). Similarly, we did not detect any sign of perforation or ulceration in the sampled birds. Other studies based on a size-adequate and homogenous sample also failed to find relationships in both adults (Yamashita et al., 2011) and fledglings (Carey, 2011). However, other consequences could be hidden. The ingested plastic particles by seabirds accumulate contaminants as polychlorinated biphenyls (PCBs) and organochlorine pesticides (Colabuono et al., 2010). Positive relationships between plastic loads and PCBs have been recorded in other petrel species, such as the great shearwater Puffinus gravis and the short-tailed shearwater Puffinus tenuirostris (Ryan et al., 1988; Yamashita et al., 2011), suggesting that plastics are an important source of persistent organic pollutants. In fact, Tueten et al. (2009) have experimentally demonstrated that low chlorinated PCBs absorbed to the plastics can be transferred to the tissues of streaked shearwater Calonectris leucomelas fledglings (see also Yamashita et al., 2011 for a correlative study). The low chlorinated congeners constitute more than $50 \%$ of total PCBs in the adult Cory's shearwaters from the Canary Islands (Roscales et al., 2010). Assessing the plastic contribution to the high concentration of low chlorinated congeners is crucial to understand the pollutant absorption process, but also to recognize the potential hidden effects of plastic ingestion.

An open question is how adult Cory's shearwaters ingest these small plastic particles (note that this species has a bill size of five centimeters and the normal size of their prey is about $10 \mathrm{~cm}$ long; den Hartog and Clarke, 1996; Granadeiro et al., 1998; Xavier et al., 2011). Plastics may be obtained from prey (secondary ingestion). Little is known about the plastic ingestion prevalence on lower trophic level marine organisms. A 35\% prevalence of plastic in the guts of pelagic fish has been recently recorded and some characteristics (size, mass and color) of those plastic items overlap with the plastic fragments found in our study (see Boerger et al., 2010). However, there is no information on plastic ingestion by squids, the main prey of Cory's shearwater in the Canaries (den Hartog and Clarke, 1996). Another non-exclusive hypothesis is that the small size of plastic particles is due to fragmentation of particles in the gut of birds.

Basic information on plastic debris, such as size, mass, or composition is quite limited for the North Atlantic Ocean (see MorétFerguson et al., 2010). Plastics transferred by adults to fledglings are longer than the reported for the western North Atlantic Ocean, suggesting some type of selection on plastics (by shearwaters or by their prey). Thus, $69 \%$ of plastic particles collected in the ocean measured between 2 and $6 \mathrm{~mm}$ (Morét-Ferguson et al., 2010), while plastics of similar sizes ingested by Cory's shearwaters constituted only $44 \%$ of total plastic particles. There is no information on the color of plastics at North Atlantic Ocean. Without this information, we cannot assess if shearwaters are selecting for any particular color. White plastics predominated in the guts of Cory's shearwater fledglings, being smaller than other colored plastics. Light colors (mainly white) were also the most frequent colors of plastic items found in the gut contents of adult seabirds (Ryan, 1987b; Moser and Lee, 1992; Vlietstra and Parga, 2002), but also of short-tailed shearwater fledglings (Carey, 2011).

Our sampling procedure for plastic marine debris monitoring is, in principle, less biased than the majority of previous studies based on beached birds or birds accidentally killed by fisheries (e.g. Ryan, 2008; Colabuono et al., 2009; van Franeker et al., 2011; Carey, 2011). Petrel fledglings stranded by artificial lights constitute a homogeneous sample, as these birds belong to the same cohort (i.e. they are all the same age). In addition, they constitute an unbiased sample regarding body condition, as the fatal collision of fledglings stranded by light pollution is not dependent on their body condition (Rodríguez et al., 2012b). Furthermore, light pollution has increased during the last years, as well as, the number of fledglings disoriented by artificial lights (Rodríguez et al., 2012a). Despite of mitigation measures and the enhancement of rescue campaigns, light pollution will inevitably bring over fatally stranded fledglings during the next coming years. As with the northern fulmar from the North Sea, where a monitoring program is beneficiating from an international co-operation (see van Franeker et al., 2011), we propose to use light-dead seabirds to monitor and quantify trends in marine litter in the Canary Current, but also to evaluate other indicators of marine environmental health (see Mallory et al., 2010). This large marine ecosystem holds one of the most productive fisheries in the world nowadays. Therefore, establishing an adequate monitoring program should be a priority to provide useful information for policy decisions.

\section{Acknowledgements}

Special thanks to the anonymous people who kindly cooperate with the rescue campaigns of shearwaters attracted to lights, and to the staff of La Tahonilla wildlife rehabilitation center for their collaboration. Domingo Felipe Rodríguez, Juan Curbelo, Ricardo Medina and María Teresa G. Santamaría helped us during the 
measurement and analysis of gut contents. Juan J. Negro improved the English grammar.

\section{References}

Alder, J., Sumaila, U.R., 2004. Western Africa: a fish basket of Europe past and present. Journal of Environmental and Development 13, 156-178.

Andrady, A.L., Neal, M.A., 2009. Applications and societal benefits of plastics. Philosophical Transactions of the Royal Society B 364, 1977-1984.

Arcos, J.M., Bécares, J., Rodríguez, B., Ruiz, A., 2009. Áreas Importantes para la Conservación de las Aves Marinas en España. LIFE04NAT/ES/000049-Sociedad Española de Ornitología (SEO/BirdLife), Madrid.

Barnes, D.K.A., Galgani, F., Thompson, R.C., Barlaz, M., 2009. Accumulation and fragmentation of plastic debris in global environments. Philosophical Transactions of the Royal Society B 364, 1985-1998.

Bester, A.J., Priddel, D., Klomp, N.I., 2010. Diet and foraging behaviour of the Providence petrel Pterodroma solandri. Marine Ornithology 39, 163-172.

Boerger, C.M., Lattin, G.L., Moore, S.L., Moore, C.J., 2010. Plastic ingestion by plastic ingestion by planktivorous fishes in the North Pacific Central Gyre. Marine Pollution Bulletin 60, 2275-2278.

Bond, A.L., Jones, I.L., Williams, J.C., Byrd, G.V., 2010. Auklet (Chradriiformes: Alcidae, Aethia spp.) chick meals from the Aleutian Islands, Alaska, have a very low incidence of plastic marine debris. Marine Pollution Bulletin 60, 13461349.

Campredon, P., Cuq, F., 2001. Artisanal fishing and coastal conservation in West Africa. Journal of Coastal Conservation 7, 91-100.

Carey, M.J., 2011. Intergenerational transfer of plastic debris by shot-tailed shearwaters (Ardenna tenuirostris). Emu 11, 229-234.

Colabuono, F.I., Barquete, V., Domingues, B.S., Montone, R.C., 2009. Plastic ingestion by Procellariiformes in Southern Brazil. Marine Pollution Bulletin 58, 93-96.

Colabuono, F.I., Taniguchi, S., Montone, R.C., 2010. Polychlorinated biphenyls and organochlorine pesticides in plastic ingested by seabirds. Marine Pollution Bulletin 60, 630-634.

Copello, S., Quintana, F., Pérez, F., 2008. Diet of the southern giant petrel in Patagonia: fishery-related items and natural prey. Endangered Species Research 6, 15-23.

den Hartog, J.C., Clarke, M.R., 1996. A study of stomach contents of Cory's shearwater, Calonectris diomedea borealis (Cory, 1881) (Aves: Procellariidae), from the Macaronesian Islands. Zoologische Mededelingen 70, 117-133.

Derraik, J.G.B., 2002. The pollution of the marine environment by plastic debris a review. Marine Pollution Bulletin 44, 842-852.

Granadeiro, J.P., Monteiro, L.R., Furness, R.W., 1998. Diet and feeding ecology of Cory's shearwater Calonectris diomedea in the Azores, north-east Atlantic. Marine Ecology Progress Series 166, 267-276.

Gregory, M.R., 2009. Environmental implications of plastic debris in marine settingsentanglement, ingestion, smothering, hangers-on, hitch-hiking and alien invasions. Philosophical Transactions of the Royal Society B 364, 2013-2025.

Hutton, I., Carlile, N., Priddel, D., 2008. Plastic ingestion by flesh-footed (Puffinus carneipes) and wedge-tailed (P. pacificus) shearwaters. Papers and Proceedings of the Royal Society of Tasmania 142, 1-6.

Hyrenbach, D.W., Nevins, H., Hester, M., Keiper, C., Webb, S., Harvey, J., 2009. Seabirds indicate plastic pollution in the marine environment: quantifying spatial patterns and trends in Alaska. In: Williams, M., Ammann, E. (Eds.), Marine debris in Alaska: coordinating our efforts. Anchorage, Alaska, pp. 57-61, Proceedings of the Marine Debris in Alaska Workshop February 14-15, 2008.

Laist, D.W., 1987. Overview of the biological effects of lost and discarded plastic debris in the marine environment. Marine Pollution Bulletin 18, 319-326.

Laist, D.W., 1997. Impacts of marine debris: entanglement of marine life in marine debris including a comprehensive list of species with entanglement and ingestion records. In: Coe, J.M., Rogers, D.B. (Eds.), Marine Debris, sources, impacts and solutions. Springer-Verlag, New York, pp. 99-139.

Mallory, M.L., Robinson, S.A., Hebert, C.E., Forbes, M.R., 2010. Seabirds as indicators of aquatic ecosystem conditions: a case for gathering multiple proxies of seabird health. Marine Pollution Bulletin 60, 7-12.
Morét-Ferguson, S., Law, K.L., Proskurowski, G., Murphy, E.K., Peacock, E.E., Reddy, C.M., 2010. The size, mass, and composition of plastic debris in the western North Atlantic Ocean. Marine Pollution Bulletin 60, 1873-1878.

Moser, M.L., Lee, D.S., 1992. A fourteen-year survey of plastic ingestion by Western North Atlantic seabirds. Colonial Waterbirds 15, 83-94.

Petry, M.V., Krüger, L., Fonseca, V.S.S., Brummehaus, J., Piuco, R.C., 2009. Diet and ingestion of synthetics by Cory's shearwater Calonectris diomedea off southern Brazil. Journal of Ornithology 150, 601-606.

Rodríguez, A., Rodríguez, B., 2009. Attraction of petrels to artificial lights in the Canary Islands: effect of the moon phase and age class. Ibis 151, 299-310.

Rodríguez, A., Rodríguez, B., Lucas, M.P., 2012a. Trends in numbers of petrels attracted to artificial lights suggest population declines in Tenerife, Canary Islands. Ibis 154, 167-172.

Rodríguez, A., Rodríguez, B., Curbelo, A., Pérez, A., Marrero, S., Negro, J.J., 2012b. Factors affecting mortality of shearwaters stranded by light pollution. Animal Conservation. http://dx.doi.org/10.1111/j.1469-1795.2012.00544.x.

Roscales, J.L., Muńoz-Arnanz, J., González-Solís, J., Jiménez, B., 2010. Geographical PCB and DDT patterns in shearwaters (Calonectris sp.) breeding across the NE Atlantic and the Mediterranean archipelagos. Environmental Science and Technology 44, 2328-2334.

Ryan, P.G., 1987a. The effects of ingested plastic on seabirds: correlations between plastic load and body condition. Environmental Pollution 46, 119-125.

Ryan, P.G., 1987b. The incidence and characteristics of plastic particles ingested by seabirds. Marine Environmental Research 23, 175-206.

Ryan, P.G., 1988. Effects of ingested plastic on seabird feeding: evidence from chickens. Marine Pollution Bulletin 19, 125-128.

Ryan, P.G., 2008. Seabirds indicate changes in the composition of plastic litter in the Atlantic and south-western Indian Oceans. Marine Pollution Bulletin 56, 14061409.

Ryan, P.G., Connell, A.D., Gardner, B.D., 1988. Plastic ingestion and PCBs in seabirds: is there a relationship? Marine Pollution Bulletin 19, 174-176.

Ryan, P.G., Moore, C.J., van Franeker, J.A., Moloney, C.L., 2009. Monitoring the abundance of plastic debris in the marine environment. Philosophical Transactions of the Royal Society B 364, 1999-2012.

Spear, L.B., Ainley, D.G., Ribic, C.A., 1995. Incidence of plastic in seabirds from the Tropical Pacific, 1984-91: relation with distribution of species, sex, age, season, year and body weight. Marine Environmental Research 40, 123-146.

Thompson, R.C., Moore, C.J., vom Saal, F.S., Swan, S.H., 2009. Plastics, the environment and human health: current consensus and future trends. Philosophical Transactions of the Royal Society B 364, 2153-2166.

Tueten, E.L., Saquing, J.M., Knappe, D.R.U., Barlaz, M.A., Jonsson, S., Bjorn, A., Rowland, S.J., Thompson, R.C., Galloway, T.S., Yamashita, R., Ochi, D., Watanuki, Y., Moore, C., Viet, P.H., Tana, T.S., Prudente, M., Boonyatumanond, R., Zakaria, M.P., Akkhavong, K., Ogata, Y., Hirai, H., Iwasa, S., Mizukawa, K., Hagino, Y., Imamura, A., Saha, M., Takada, H., 2009. Transport and release of chemicals from plastics to the environment and to wildlife. Philosophical Transactions of the Royal Society B 364, 2027-2045.

van Franeker, J.A., Blaize, C., Danielsen, J., Fairclough, K., Gollan, J., Guse, N., Hansen, P.L., Heubeck, M., Jensen, J.K., Le Guillou, G., Olsen, B., Olsen, K.O., Pedersen, J., Stienen, E.W.M., Turner, D.M., 2011. Monitoring plastic ingestion by the northern fulmar Fulmarus glacilis in the North Sea. Environmental Pollution 159, 2609-2615.

Vlietstra, L.S., Parga, J.A., 2002. Long-term changes in the type, but not amount, of ingested plastic particles in short-tailed shearwaters in the southeastern Bering Sea. Marine Pollution Bulletin 44, 945-955.

Xavier, J.C., Magalhães, M.C., Mendonça, A.S., Antunes, M., Carvalho, N., Machete, M., Santos, R.S., Paiva, V., Hammer, K., 2011. Changes in diet of Cory's shearwaters Calonectris diomedea breeding in the Azores. Marine Ornithology 39, 129-134.

Yamashita, R., Takada, H., Fukuwaka, M.-A., Watanuki, Y., 2011. Physical and chemical effects of ingested plastic debris on short tailed shearwater Puffinus tenuirostris, in the North Pacific Ocean. Marine Pollution Bulletin 62, 2845 2849.

Young, L.C., Vanderlip, C., Duffy, D.C., Afanasyev, V., Shaffer, S.A., 2009. Bringing home the trash: do colony-based differences in foraging distribution lead to increased plastic ingestion in Laysan albatrosses? PLoS One 4, e7623. 